\title{
Encouraging girl child education in my village
}

By Delphine Etongwe 


\begin{abstract}
My critical reflection will be drawn from an experience I had just a year after my graduation from the university where I was appointed as one of the X-students to lead a student cultural week in my village with the theme "raising awareness on education". At the university, I was a member of my association in which students from my tribe generally come together to promote unity and encourage others in education. My role was to present a discourse on girl child education all the entire villagers who were gathered at the village square that evening. A high dropout rate at school and illiteracy are major problems in my region, in which there is still a great deal of gender disparity when it comes to educating children, especially the girl child. This programme is in line with the government's policy of promoting education in my country, whose priority is for education to reach the grass-roots communities.
\end{abstract}

Keywords: education, empowerment, gender

This essay is a reflection of the experience I had in my village during a one-week cultural meeting with students coming from all over the subdivision, in which my village was the host village. I left for the village same day the cultural week was to begin, since my city is not far from my village. But because it has been a while since I went to the village, I did not have an idea of how bad the roads were, so I arrived very late to the village. This gave me very little time to familiarise myself with the environment or talk with a few old friends to ease the tension before my presentation. I could remember quite a good number of people who I saw that evening, because I did my primary education in the village. The programme had to start almost immediately after I arrived and I was the third speaker that evening, presenting my talk on girl child education and some of the advantages that it brings. I was tense, but I made my presentation as simple as possible so that everyone could understand since it was not in my local language, but in English. Everything went as well as planned for the first evening and there were quite a lot of activities to help make the week an interesting one.

\title{
Why should a woman's office be in her husband's kitchen?
}

Before the activities began the following morning, I decided to visit a few of the families I could remember in order to see some old friends and to have a chat. It had been a long time since I saw them because unless you are going to visit, there is no reason to go there and I had been in the city for some years at school, and my family is based in the city. I have a friend the same age as me that I was really close to who was not only my friend but also my classmate while I was in primary school in the village. I met everyone in the house except for her father and they were all happy to see me; we talked for a while and they were asking a lot of questions concerning my presentation the previous night. Her mum was really excited to see me and to see much I had grown, as well as being very happy to see how educated and intelligent a woman I had turned out to be. Then all of a sudden she became sad, and when I asked her if she was okay, she told her story to me.

She told me how her husband had deliberately refused to send my friend and her two sisters to school because they were female children. According to the husband, a female education is a waste of resources. At that moment a lot of things were running in my mind, or better still, I was trying to figure out what his reasons might be. It was quite pathetic to hear this, but I was curious to have a word with the father before I left, so I waited patiently for him to come back from the farm. Shortly after his return I waited for him to have his food and rest for a while, then I walked towards the bamboo chair where he was relaxing and greeted him. Not knowing where to begin the conversation I told him that my father had sent his greetings, and when I saw the smile on his face I opened up by asking him why his female children were not in school. Throwing his face to the wall, he replied "a woman's office should be in her husband's kitchen." To him, female children should stay at home, while male children go to school. 
The female child is considered to be a second mother who helps take care of the younger children, and when it is time for marriage, that is what she is meant for. Then suddenly he turned in my direction and said, "your office should be in your husband's kitchen and you should not aspire to be in control when men are there." I was shocked and confused upon hearing this from my friend's father, so I left and wondered how to carry on with my task. Many girls in my village were going through the same pain as my friend. Due to a lack of education, most young girls in the village end up in early child birth, while some of the girls are taken into the cities to serve as housemaids with little or no remuneration for their services. When I left from my friend's house, I was a bit confused on how to continue my task before the end of the week because I realised the problem was not only coming from one direction.

\section{A meeting with the chief and the elders of the village}

For a moment, I thought it would be a better idea if I arranged a meeting with the village authorities. The reason for this meeting was to raise the awareness of the village authorities, to also try to better understand the difficulties involved and to see how to solve our own problems in the community. So I went to the chief of the village to seek his permission to call for a meeting with the council of elders. The chief happens to be a close friend of my father, and he comes to visit us each time he visits the city. My personal relationship with the chief made it easy for my request to be granted, knowing that it was for the benefit of our own community. I must say my meeting with the elders was not an easy one. As a woman, I was expected to stand all throughout the meeting while talking, which to them is a sign of respect, not only as elders, but also as men. Giving my educational achievements and the ethnic group I come from, many people find it difficult to accept that I am from the same village that I am talking about in my essay. This is simply because the majority of girls from my tribe do not attend school to get a higher education. My father is one of those people who believe in giving the best to their children, especially when it comes to education. My father took it upon himself as a challenge to make sure that none of his children would be illiterate like most of our people, in addition to the fact that his father vehemently refused to send his children to school, including my father. Hence, knowing how difficult it was for him to struggle on his own in order to survive in life, he vowed never to be like his father.

\section{Looking for strength in the community}

In carrying out my work in the village, my approach was to implement the various ways that would help me in recognising the personal, cultural and structural phenomena of the oppression experienced by female children. In doing so, I had to use different approaches in order to understand these phenomena. First, I organised an open discussion for the entire population who gathered at the village square that evening on how important education is for a girl child. Second, I also organised a meeting with the elders who run the day-to-day affairs of the village to make them see the importance with me of educating girls, while last but not least I visited most of the homes in the village in an attempt to educate them on friendly terms about the importance of girl child education. Following the strength perspective theory which I implemented in my work, I was faced with a number of difficulties that really caused me to have a rethink of some of the weaknesses of this approach, as stated by Healy (2005). The strength perspective appears naive in relation to the barriers, particularly the structural obstacles that many villagers experience in realising their goals, let alone their hopes and dreams. This can be seen in the lack of classrooms in the already existing community primary and secondary school, as well as the lack of qualified teachers to teach the children. With the aforementioned problems, most parents feel overburdened in sending their children to big cities for schooling, thus they prefer their female children to stay home and care for the younger ones. Having all this in mind, I felt reluctant and thought it was going to be impossible for me to achieve my reasons for being in the village, but I was ready to move ahead with my task. 
Thus, I tried to sensitise the elders and the school committee members during my meeting in the village on how to improve their efforts by creating a strong parent-teacher association, in addition to creating work sessions for the community to build, maintaining classrooms, etc. I also attempted to sensitise more families on the benefits of educating their girl child, which would go a long way towards improving the economic condition of the family in the long run, and also help in bringing about development in the area. Lastly, I talked about the steps taken by the organisation I worked for that is giving assistance in the form of scholarships to young girls, which motivated many to work hard, thereby reducing the illiteracy rate in the area. There are other factors which caused me to encounter a lot of difficulties during my task in the village such as my gender, my age and my social class. One of the biggest barriers I faced when carrying out my work in the village was that of gender discrimination. Gender inequality is one of the major problems facing the community or society which I come from, bearing in mind that I come from a patriarchal society. Gender inequality has the largest negative effect on the deprived women and society as a whole will also lose, which brings more poverty, more malnutrition, more illness and other forms of deprivation (World Bank, 2001, p. 73).

Looking at the way situations unfolded in my work, my gender can be seen as an important consideration. In fact, it is difficult for me to imagine that these incidents would have occurred at all, let alone have created the same impact, if I was male. In trying to analyse my critical incident, I will be looking at my position as a woman in my village. As a woman in my area, I am culturally viewed as secondary and never brought into the limelight when it comes to issues of development. Such chauvinist attitudes are rooted in the cultural setting of the people, in which a woman's place is still believed to be in the kitchen and making babies. This aspect has continuously manifested itself through the bias in the sex preference of child education of males in the society where I come from. Such a practice deprives the girl child of an opportunity to attend school, achieve an education and be able to make informed life decisions. There has to be the recognition of an empowerment approach that acknowledges the unequal social relations of gender and advocates for the redistribution of power among men and women (Pearson, 1992).

For example, a failure to empower women to let them contribute to the development of the community is due not only to a resistance to the inclusion of women in development projects, but also in looking at women only in their roles as mothers, "rather than active agents, workers, managers of resources" (Anderson and Chen, 1988). My friend's father and most of the men in my community are those who do not believe in the education of women, including their female children and wives. The adherents of the belief that, "The place of the woman is in the kitchen", have compromised women's desire for quality education by making things difficult for women when it comes to educational development. Such men prefer to marry illiterates as wives for fear that an educated woman is too assertive, domineering, free, and in general a threat to the male-dominated society.

Upon reflection, I felt for a moment that I would not have been treated the way I was during the meeting with the elders and the chief, and also during my visit to my friend's house, if I was male. Since I come from a society where men are in control, it is natural for them to see me as a weaker sex compared to my male counterparts. At first, I never imagined that my gender was going to pose a problem during the meeting. If I would have known about this beforehand, I would have asked one of my other male friends to speak for me in the meeting, which in my case would have made things easier than it was.

Considering the fact that I was a young girl, it brought a lot of misconceptions in the minds of the elders, since to them I was only a child who knew nothing about tradition and the customs of our people. To some extent, my social class also posed a lot of difficulties, in the sense that it was interpreted by the majority that I am educated because my family could afford it and did 
not necessarily have to discriminate between males or females in terms of choices. Knowing that most of the villagers are poor and can hardly take care of themselves, let alone send their children to school, we were not in the same category of social class. This strained my relationship with the villagers, as they thought they had nothing to do for or offer to people of my social class. Therefore, I tried as much as possible to put away my excesses as I interacted with the villagers during my visit to some of my friends and the homes of the people I had talked with, and I ate and drank together with them in order to make them feel at ease.

During my meeting with the elders, I was made to stand all throughout. In order to find answers for the way I was treated, I understood later on that it was a way of making me feel subordinated to them as men. They were actually trying to protect the power or authority they commanded as men and elders of the land. I considered both incidents to be critical because it challenged me to reconsider the way I see myself as a social worker and the way I practice. According to the elders, being a woman to them means refraining from village affairs since that is considered to be the duty of men. It is rare for a woman to be in the midst of decision makers in the village, as the normal practice is that women have their own meetings and can only carry matters which are beyond them to the council of elders and the chief for the final say.

Both incidents helped me to realise who I am today as a social worker and with my practice. My task helped me to realise how to integrate with people from different classes and to learn the views they had about me. One example can be seen in the way I associated myself with the villagers, spending hours and eating together during my discussions with them. Knowing that the villagers had their own way of life and how they carried out their daily activities, I tried as much as possible to situate myself in their way of life in order to reduce the class differences to allow for better communication. In dealing with my task, which is all about changing a community from my own perspective as a community worker, there are some ethical issues which may arise.

A question that I would like to ask myself is who am I to tell the villagers what is best for them? And is female education so important that I can press my opinion on the villagers, and if so, why? I would like to understand these questions in order to improve on my practice as a social worker today.

As a community worker in my own village, my role is to bring about changes that will be of benefit to all. As a result, I am not imposing on the villagers to do as I say, but to look at the positive effects of what I am telling them; in that way, they are the ones to choose whether they want to be part of the great change or to remain in their old ways. I believe that being a female child and passing through school is a good experience that I would like others to be a part of, sharing the knowledge I have achieved and also trying to liberate other girls from their oppression, and the best way to do this is through such awareness schemes. That is why together as a team, we introduced a community-based planning which goes a long way towards encouraging families to send their girls to school. Examples of such community-based planning include forming parents' associations, developing income-generating projects such as school gardens, in which the pupils and students cultivate some crops to sell to the locals to generate some income for the school, creating mothers' and fathers' councils to increase local investments in girls' quality education and conducting awareness-building events about the importance of education. Hence, as stated above, as a social worker or a community worker my main aim was to bring about positive changes in the lives of most young girls in the village, which would go a long way in improving the quality of life of our people in the future. As a daughter from the same village, I have my people's interest at heart, thus I would not want to mislead them to do what is not right. Change must begin from the inside, that is to say the people are the ones who must strive for such a change within their own community. Due to the low level of education of most young women in the community, the rate of poverty is growing at an alarming rate. For this reason, the village needs community workers to help 
them achieve social change by helping them to build on their own capacities. This can only be achieved by using what the community already has as resources to bring about these changes.

In order to answer the question as to why female education is important and why I need to press my opinion on the villagers, I will be bringing out some of the advantages that education will have in the community as a whole, and to a woman's life in particular.

Education will allow most of the women in this community to be self-dependent and not dependent on others, as is the case right now. In so doing, the girls or women will marry late and care for their children in the proper manner, thereby reducing the problem of early child birth in the community. Families will become smaller and healthier as a result of the women being educated and knowing how to control child birth and malnutrition. Education will also help these women to know their rights and gain the confidence to claim such rights. When a woman is educated she is likely to be in the labour force, which implies that she will be able to assist her husband in running the affairs of the family, thus improving the economic situation of the entire family. This will help the present situation of the women solely being housewives, with little or nothing to contribute to the daily running of their families in this area. There are just so many benefits that education will bring to the lives of women, provided that they decide to be part of the great change.

Knowing how important education is in the life of a woman in particular, as well as the community in general as stated above, it is therefore necessary for the villagers to participate by achieving this great change in our community. In helping to raise local awareness in my community about the importance of girls'education, I carried out community sensitisation campaigns regarding the advantages of girls' education, which have been effective in increasing parent and community involvement in project activities. Additionally, campaigns have proven to be integral in educating girls and young women, as all information is relevant to local beliefs and practices. Examples of such campaigns include community-based planning that encourages families to send girls to school, even if there has been some form of community action that has taken place in the past. Examples of some community action which I talked about are the creation of community schools, the forming of parents' associations, the development of income-generating projects such as school gardens in which the pupils and students cultive some crops for sale, the creation of mothers' and fathers' councils to increase local investment in girls' quality education and the conducting of awareness-building events about the importance of education. All of these were introduced in my village, which encouraged the above movements to not relent in their efforts to achieve this goal; thus, I tried as much as possible to sensitise the villagers to the various ways in which they could continue to manage such groups in order to yield positive results, while having in the back of my mind that education is important for everyone, but it is necessarily more significant for girls and women. This is true not only because education is an entry point to other opportunities, but also because the educational achievements of women can have a triple effect within the family and to the community at large.

Despite the advantages that education has in the life of young girls and women, women's literacy rates are significantly lower than men in the region. Because of this, closing the wide gap between men and women in terms of education was the main reason why we organised this cultural week in the village, which is also a major development priority for the country as a whole.

\section{The strength perspective focuses on possibilities}

The strength perspective is one of the theories that I implemented during my task, which is linked with empowerment approaches as stated by Saleeby (1997) and van Wormer (2001). 
Many features of the empowerment approach are consistent with the strength perspective (see Parson et al., 1998; Payne, 1997). Both approaches aim to recognise and build service users' capacity to help themselves and their communities, and to promote a mutual learning partnership between workers and service users. The strength perspective is a strategy for seeing a way to learn to recognise and use what is already available to them (the service users). The professional person therefore becomes a translator who helps people see that they already possess much of what they need to proceed on their chosen path (Healy, 2005, p. 153). .

Working in accordance with some of the principles of this approach, I first have to adopt an optimistic attitude. This means that I have to be positive towards the villagers, which enables me to see whether I could see let alone build on the strengths and resourcefulness of the villagers (Turnell \& Edwards, 1999, p. 62). This principle simply tells me to rely on the positive aspects that can bring about an increase in the quality of life for the villagers. Therefore, my aim is not to rely on the problems they are going through in their lives, but to support them to see what strengths they have in order to change their situation. I tried to sensitise the community leaders on how they could go about maintaining the already existing schools in the village, and how to employ teachers who are to be paid by the community as a whole through the parent-teacher association.

Secondly, relying primarily on the assets of the villagers requires that I recognise their assets because one can only build on strengths, not on deficits. This can be achieved by the way I listen to the villagers' accounts of their situation. A strength approach to listening requires one to be on the lookout for signs of capacity and resourcefulness, rather than only the problems in their lives.

Working towards the long-term empowerment of service users is also one of the principles of the strength perspective. One way of accomplishing this is to focus on the future possibilities, instead of the past problems, of the village. Consequently, rather than trying to uncover the causes of the problems, my work during my task was oriented towards uncovering the hopes and dreams for the future for most of the young girls in my community. In using this approach, I tried to affirm the villagers' resilience and capacities, including those developed through adversity, rather than view them as victims of their situations or social structure.

Using anti-oppressive theory to accomplish my task in the village, I used the various practice principles involved in this theory. In accordance with the first practice principle, I tried placing myself as one of the women in the village. This helped me to better understand the social context in which they find themselves; this can be seen during my task in the village, where despite my social background I made most of the girls and women my friends, especially when I tried to renew the ties between me and my old friends by paying visits to their homes and sharing in their stories. This helped me in my practice, as it gave me an insight into the extent of the oppression that most women and girls were going through.

In looking at the second practice principle, which is that of the critical assessment of service users' experiences of oppression, I realised that the oppression that the women and girls in my community experienced is as a result of the unequal power relation between men and women. The type of social division which existed within this community was that of gender, hence the major problem of gender inequality between men and women. I also had to bear in mind that I had to be aware of the way in which language can reflect power differentials and have an impact on people.

With regard to the third principle, which is that of empowering the service user, I tried to empower men, women and children in order to overcome the cultural, institutional and structural, as well as personal, obstacles which have such a great control over their lives (Dalrymple \& Burke, 
1995, pp.52-3; Thompson, 1997, p.156). This can be seen in the open discussion during my presentation on the very first day of my task, in my meeting with the authorities in the village and also in discussions which I held during my visit around the village, particularly with the women and girls in the village who were the most vulnerable population. At the interpersonal level, the approach was to empower them by encouraging most of the oppressed girls and women to share their feelings of powerlessness (Dalrymple \& Burke, 1995, pp.53-4).

Additionally, the awareness I raised during my task helped the people to understand how structural and cultural injustices shape their experiences of oppression, which highlights that they are not alone in their experiences of powerlessness (Mullaly, 2002, pp. 180; Thompson, 2003 , p. 223). Using the same principle, I identified that a further barrier to empowerment may lie in the villagers' lack of capacities, or in the confidence in their capacity to act. At an institutional level, I tried to promote change in some of the organisations directly involved in the area of education. I urged the authorities concerned to build a strong parent-teacher association to help in the community's primary and secondary schools.

The fourth principle talks about "working in partnership", which means that women should be included as much as possible with their fellow citizens in the decision processes which affect their lives' (Dalrymple and Burke, 1995, p. 64). Such awareness on the part of the women will help them to gain control over their lives, thereby allowing them to contribute or make decisions that concern their families. In spite of this unequal power relationship, partnership demands that we value the individual by, for instance, showing respect for their perspectives and their lived knowledge (Burke \& Harrison, 2002; Mullaly, 2002).

The last principle is that of minimal intervention, which requires that we enact social control to help prevent harm to the people, especially in the case of a high-risk environment. This helps to reduce the oppressive and disempowering dimension of my intervention, as my aim is to intervene in the least intrusive and least oppressive ways possible (Payne, 1997, p. 261). Therefore, my focus is to promote gender equality among my tribe and to not touch on any pain they were undergoing, either personally or socially. For example, when my friend's mother told me what was going on in her family and how helpless she was, my primary objective was not to make her feel bad about her situation, but to know how I could intervene in to help solve her problems. Such stories helped during my meeting with the elders, knowing that her husband was one of the elder's of the village. I tried to sensitise the men of the village that women have to have equal rights, particularly in the sphere of education with their male counterparts.

\section{Who am I as a social worker today?}

This entire experience has changed the way I view myself as a social worker, and also made me to realise that I have to strive towards understanding the needs of people and how to approach them, especially when it comes to different contexts. Thus, as a social worker today, one of my priorities is to understand the needs of the people I work with and to also be able to provide support that will go a long way towards benefitting them, as opposed to impacting knowledge which the user will not be able to understand or make use of. One example of using empowerment in my work will be to strive towards a practice that will allow me to be able to identify both the weaknesses and strengths of my user.

My task has also made me come to realise that I have to have confidence in myself in order to help others. Examples of this can be seen in the incidents in which I visited my friend and the father used words that were degrading for the simple reason that I am a woman, as well as in the meeting which took place between the elders and myself. I realised that the power and authority which I tried to preserve during my task would be questioned, as some villagers did not see me as a social worker, but as a woman who was considered to be weak. Working with people from 
the lower class and coming into contact with this vulnerable population in my task has helped me to have a rethink of the way I approach and see into the needs of my users. Working with the people in my village has helped me to redefine my actions and role as a social worker by making it easier for me to interact with people from a different class. Today, my approach to working with the community and oppressed people has changed. As seen during my visit to many of their houses, associating myself with the villagers by eating and talking together has changed my personal beliefs about people from a lower status, in addition to the oppressed population in general. I have learned to be patient and consistent in my work in order to achieve my aims, and not to impose on the user.

An important role as a social worker is to raise the consciousness of the service user by helping them to see the causes of the problems that have led to their unjust social structure (Healy, 2005). The modern critical social work paradigm has put much emphasis on how to empower service users to act collectively, as well as how to facilitate social change. This collective action is envisaged as a means of making a society free of all forms of oppression and domination (Fay, 1987 in Healy, 2005). Thus, through collective action, the oppression undergone by female children and women in the villages can be put to an end. My experience of working with the people today has created more knowledge and given me a better understanding of myself and how to carry out my practice. For example, I have learned to be more considerate to other people, especially in relation to the oppressed and the poor. I find it much easier to integrate myself with people from other class groups, particularly the lower class, and to share in their world. Working with my own people has made me more patient than I was before and also allowed me to believe in myself. My approach in working with the community, as well as vulnerable and marginalised groups, has been greatly changed. Today as a social worker, my priority is to listen and know the feelings and actions of my service user in order to provide solutions that will go a long way towards changing their lives. This can be best achieved by understanding the context in which they live in order to build on their capacities and strengths, and not to impose my own knowledge which will not be understood. The challenges in my task have allowed me to see myself not only as a woman whose office should be in the kitchen and be relegated to the background, but as one who can contribute in changing society socially, economically and even culturally.

\section{References}

- Burke, B. \& Harrison, P. (2002). 'Anti-Oppressive Practice', In R. Adams, L. Dominelli \& M. Payne (Eds.), Social Work: Themes, Issues and Critical Debates, $2^{\text {nd }}$ edition (Basingstoke: Palgrave, 2002).

- Dalrymple, J. \& Burke, B. (1995). Anti-oppressive Practice: Social Care and the Law (Buckingham: Open University Press, 1995).

- Fay, B. (1987). Critical Social Science: Liberation and its Limits (Ithaca: Cornell University Press, 1987).

- Healy, K. (2005). Social Work Theories in Context, Creating Framework for practice, Palgrave Macmillan, New York.

- Mullaly, B. (2002). Challenging Oppression: 'A Critical Social Work Approach' (Ontario: Oxford University Press, 2002).

- Parsons, R., Gutierrez, L. \& Cox, E. (1998). 'A Model for Empowerment Practice', In L. Gutierrez, R. Parsons, \& E. Cox (Eds.), Empowerment in Social Work Practice: A Sourcebook (Pacific Grove: Brooks/Cole Publishing Company, 1998).

- Payne, M. (1997). Modern Social Work Theory, $2^{\text {nd }}$ edition (Basinstoke: Macmillan, 1997).

- Pockett, R. \& Giles, R.(2008). Critical Reflection: Generating theory from practice, Darlington Press, Sydney.

- Saleebey, D. (1997). 'Introduction: power in the people', in The Strength perspective in social work practice, $2^{\text {nd }}$ edition (New York: Longman, 1997). 
- Thompson, N. (2003). Promoting Equality: Challenging Discrimination and Oppression (Basingstoke: Palgrave Macmillan, 2003).

- Turnell, A. \& Edwards, S. (1999). Signs of Safety: A Solution and Safety Orientation Approach to Child Protection Casework (New York: Norton, 1999).

- World Bank, (2001). Engendering Development: Through Gender Equality in Rights, Resources, and Voice, New York: Oxford University Press1). 